\section{$P-317$ 進行性前立眿䆆患者の予後について}

川崎幸病院 泌尿器科

巴ひかる、長内佳代子

【目的】当院では地域患者に対秀る在宅医療を積極的に 行っている。当院で最近経娩した進行性前立腺癌9例の治 療経過と予後について検討したので報告寸る。

【経過】前立腺癌診断時の年齡は51歳から84歳であった。 初診時進行性前立腺癌の内訳は、骨転移3例、脳転移1例、 リンバ節転移1例で、経過中増悪症例は骨転移3例、局所 再発2例であった。治療方法は2例に除垶術、7例にLHRHアコニストの投与が行われた。また7例が経過中に CAB療法を行っており、2例にVAD留置に上る局所動注 化学療法、1例に全身化学療法が施行された。

【結果】経過観察期間は2力月から78カ月である。CAB 療法を行っていた症例のうち2例で antiandrogen withdrawal syndromeと思われる症例を認めた。予㣪は死 亡6例（う亏入院2例、在宅医療2例、突然死 2 例）、軽快 通院中2例、転医1例であった。死亡症例 平均観察期間 は45.1カ月であった。
$P-318$ $5 \mathrm{FU}$ 併用療法後のデキサメサケン (DXM) 投与の効果 国立札幌病院北海道がんセンター

永森 聡・柏木 明・大室 博

【目的】我々柱 first-1 ine hormone therapy 後の再燃前立腺嵒に対 してIFN- $\alpha 2 \mathrm{a} ， 5 \mathrm{FU}$ 併用療法（併用療法）を施行L，PSAに対 するPR以上の効果が約 $50 \%$ で予後の延長子期待できることを報告 しているが，その後の維持療法に苦虑してきた。今回併用療法後に second-1 ine hormone therapy としてDXM療法を施行し，治療効 果及び予後より，併用療法後の維持療法となる可能性につを検討し た。

【対象及び方法】1993 年 9 月より1997 年 8 月までに，当科にて再 燃前立腺㿋として併用療法を 2 コース以上施行された 22 例と，その うち 1996 年 4 月以降に併用療法後の再々燃及び無効例としてDXM を投与された 10 例である。DXMは $0.75 \mathrm{mg} 1$ 日 2 回， 2 力月以 上服用することとした。治療効果杜併用療法では 2 コース後, DXM 療法では服用 2 力月後にPSA值で判定した。すた予後(平均生存 期間 )の算出は併用療法開始時よりとした。

【結果】1) PSAに対する効果は併用療法で PR以上：10 例 (45\%), $\mathrm{NC}: 5$ 例 ( $23 \%), \mathrm{PD}: 7$ 例 ( $32 \%)$, DXM療法で怯,PR以上： 6 例 (60\%), NC: 4 例 ( $40 \%)$ であった。2) 今回検討した 22 例の 平均生存期間は 20.6 力であった。3) 併用療法のみ施行された 12 例の平均生存期間が 14.2 力月てあったのに対し, DXM療法を追加 された 10 例は 27.4 力月と有意に予後の延長か諰められた $(\mathbf{p}<0.05) 。$ 【結論】PSA值でみると，併用療法の効果に関係をくDXM療法の PR以上の効果壮 $60 \%$ で PD症例を認めず，完治の期待できない再 燃前立腺澺におりて，大部分の症例て病状の進行を一時的にでる阻 此でるる可能性が示唆された。その結果として, Retrospective 検討ではあるが，併用療法後にDXM療法を追加することにより， 併用療法単独に比輘して有意な予後の延長が示され，DXM 療法は 併用療法後の維持療法として充分期待しうる治療法であった。

\section{P - 319低用量デサメサソンン内服が奏功したホルモン 抵抗性Stage D2 前立腺窑の 1 例}

滝川市立病院1)・北海道大学2)

能中 修1) - 東山 寛 ${ }^{1)} \cdot$ 藤田信司 2$) \cdot$ 日岡隆矢 ${ }^{2)}$

ホルモン抵抗性前立腺癌の予後は不良であり、確立された治 療法は未だない。今回我々は低用量のデキサメサゾンの内服 が奏功した 1 例を経験したので報告する。

【症例】65歳男性。平成7年6月貧血の精查中当科初診。直腸診 上前立腺はやや硬く、PSA100ng/dI以上(Tandem-R)で生検の結 果低分化腺㿄であった。骨シンチにて多発性転移(EOD gradeII) を認め、Stage D2前立腺癌と診断し除睪術とフルタミド $375 \mathrm{mg}$ の内服を開始。8月に肝機能低下ありフルタミドの内服を中止 するも腰痛は消失し 10 月にPSA $0.2 \mathrm{ng} / \mathrm{d}$ 以下となった。平成8年 3月PSA $2.9 \mathrm{ng} / \mathrm{dl}$ と再上昇。7月に $22 \mathrm{ng} / \mathrm{dl}$ となり腰痛が出現。 酢酸クロルマジノン $100 \mathrm{mg}$ の内服を行ったが肝機能低下あり中 止。11月にPSA $57 \mathrm{mg} / \mathrm{dl}$ となり、骨シンチにて骨病変の増悪あ り疼痛緩和のため第5腰椎周囲に25Gyの放射線照射を行った。 平成9年4月PSA250ng/dlとさらに上昇し、骨シンチにて骨病変 は増悪しEOD gradeIIIとなり、疼痛も増強がみられた。 【デキサメサソン内服後の経過】平成9年5月デキサメサソン $1 \mathrm{mg} / \mathrm{day}$ の内服を開始。開始後3週で疼痛改善がみられ、PSA $11 \mathrm{ng} / \mathrm{dl}$ と著明に下降。1力月後に疼痛は消失し 2 ヶ月後の 骨シンチにて骨病変の改善がみられ、PSAは $1.6 \mathrm{ng} / \mathrm{dl}$ と正常化 した。内服後肝機能異常を含め特に副作用はみられなかった。 平成9年10月の時点で骨シンチにて骨病変はEOD gradeIと著明 に改善し、疼痛などの症状もなく経過中である。

【結語】低用量デキサメサゾンの内服は副作用もなくホルモン 抵抗性前立腺癌の治療法のひとつとして有用と思われた。

\section{$P$-320ホルモン不応前立腺雷に対する} Diethylstilbestrol diphosphate(DES-DP)の効果 伊勢崎市民病院 "1)、群馬大学 2)

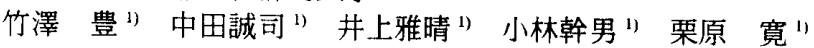
栗田 晋 ${ }^{21}$ 深堀能立 $^{2}$ 黑川公平 2) 山中英寿 ${ }^{2}$

【目的】我々はホルモン不応前立腺癌(HRPCA)に対する DES.DP の作用機序解明の一環として HRPCA 患者に DES. DP を経静脈的に投与しP S A , テストステロン $(\mathrm{T})$, 遊離テス トステロン (free T), 副腎性アンドロゲンの変動を観察した。

【対象と方法】LH-RH 治療を受けていた stage D2 患者で PSA の上昇, 臨床症状の悪化, 新病変の出現をみた 12 例をホルモ ン不応と判定した.DES-DPは $250 \mathrm{mg} /$ 日を 28 日間点滴静注し た. 患者には文書で同意を得た上で每週 P S A, T, free T, デ ヒドロエピアンドロステロン(DHEA), 硫酸デヒドロエピアン ドロステロン $(\mathrm{DHEA}-\mathrm{S})$ を測定した。【結果】患者の平均年齢 は 76.8 歳で初回治療開始から DES-DP 投与までは平均 31 ケ 月であった。PSA， DHEA-S は有意に低下した. $50 \%$ 以上 の PSA 低下は 11 例に認められた。 DES-DP 投与前 Tは 4 例 で測定可能で平均 $0.3 \mathrm{ng} / \mathrm{ml}$, free $\mathrm{T}$ は 3 例で測定可能で平均 $0.83 \mathrm{pg} / \mathrm{ml}$ であった。 DES-DP 投与 1 週以後 T, free T は全て 測定感度 $(\mathrm{T}: 0.2 \mathrm{ng} / \mathrm{ml}$, free $\mathrm{T}: 0.6 \mathrm{pg} / \mathrm{ml})$ 末満となった。【結 論】DES-DP投与により PSA は良好に下降した。DES-DPの 効果とDHEA-S 低下との関連はさらに検討を要すると考えた.

\begin{tabular}{|c|c|c|c|c|c|}
\hline & 前 & 1週後 & 2 週後 & 3遇後 & 4 週後 \\
\hline$P S A(n g / m l)$ & $614 \pm 576$ & $359 \pm 313^{*}$ & $264 \pm 235^{\text {\#* }}$ & $202 \pm 202^{\star}$ & $198 \pm 201$ * \\
\hline $\mathrm{DHEA}(\mathrm{ng} / \mathrm{ml})$ & $1.77 \pm 0.62$ & $1.65 \pm 0.41$ & $1.44 \pm 0.65$ & $1.37 \pm 0.64$ & $1.77 \pm 0.76$ \\
\hline DHEA-S $(\mathrm{ng} / \mathrm{ml})$ & $866 \pm 574$ & $686 \pm 496$ & $501 \pm 397 * \star$ & $497 \pm 338^{\star}$ & $555 \pm 477^{*}$ \\
\hline
\end{tabular}

